\title{
Weed Community and Growth Under the Canopy of Trees Adapted to THE BRAZILIAN SEMI-ARId REgION ${ }^{1}$
}

\author{
Comunidade e Crescimento de Plantas Daninhas sob a Copa de Árvores Adaptadas ao \\ Semi-Árido Brasileiro
}

\author{
SILVA, P.S.L. ${ }^{2}$, SILVA, P.I.B. ${ }^{3}$, SILVA, K.M.B. ${ }^{4}$, OLIVEIRA, O.F. ${ }^{5}$, JALES, J.D.D. ${ }^{6}$ and \\ MEDEIROS, J.L.B. ${ }^{7}$
}

\begin{abstract}
The objectives of this work were to evaluate the floristic composition and dry biomass of weeds under the canopy of seven perennial species adapted to the Semi-Arid region of Brazil, and correlate these characteristics with growth traits of the perennial species. The following perennial species were evaluated in two experiments (E1 and E2): mesquite (Prosopis juliflora), jucá (Caesalpinia ferrea), white popinac (Leucaena leucocephala), mofumbo (Combretum leprosum), neem (Azadirachata indica), sabiá (Mimosa caesalpiniaefolia) and tamarind (Tamarindus indica). In E1, the seven species were evaluated in a random block design with four replicates and nine plants per plot. In E2, evaluation comprised four species (mesquite, jucá, white popinac, and tamarind) in a random block design with eight replicates and nine plants per plot. A circle with an area of $1.77 \mathrm{~m}^{2}$ was established around the trunk of each plant, two years after they were transplanted to the permanent location. The weeds collected within this circle were cut even with the ground, classified and weighed. At this time, plant height, and crown and stem diameters were evaluated in all trees of each plot. In E1 there were no differences between tree species as to weed frequency under their canopies; however, weed growth was smaller under the canopy of sabia trees. Mesquite and sabia had the greatest plant height and crown diameter means, but only sabia had the greatest stem diameter. In E2, the perennial species were not different with regard to weed frequency and growth under their canopies, but mesquite had the greatest growth, as measured by plant height (with significant results for jucá as well) and crown and stem diameter.
\end{abstract}

Keywords: Caatinga, floristic composition.

\begin{abstract}
RESUMO - Os objetivos deste trabalho foram avaliar a composição florística e a biomassa de plantas daninhas sob a copa de sete espécies perenes adaptadas à região semi-árida do Brasil, e correlacionar essas caracteristicas com características do crescimento das espécies perenes. As seguintes espécies perenes foram avaliadas em dois experimentos (E1 e E2): algaroba (Prosopis juliflora), jucá (Caesalpinia ferrea), leucena (Leucena leucocephala), mofumbo (Combretum leprosum), nim (Azadirachta indica), sabiá (Mimosa caesalpiniaefolia) e tamarindo (Tamarindus indica). Em E1, as sete espécies foram avaliadas em blocos ao acaso com quatro repetições e nove plantas por parcela. Em E2, a avaliação compreendeu quatro espécies (algaroba, jucá, leucena e tamarindo) no delineamento de blocos ao acaso com oito repetições e nove plantas por parcela. Um círculo com área de 1,77 $\mathrm{m}^{2}$ foi estabelecido ao redor do caule de cada planta, dois anos após o transplantio dela para o local definitivo. As plantas daninhas coletadas no interior desse círculo foram cortadas rente ao solo, classificadas e pesadas. Nessa ocasião, foram avaliados os diâmetros do caule e da copa e a altura de todas as árvores de cada parcela. Em E1, não existiram diferenças entre espécies
\end{abstract}

1 Recebido para publicação em 6.11.2009 e na forma revisada em 12.3.2010.

2 Universidade Federal do Semi-Árido (UFERSA), Caixa Postal 137, 59600-970, Mossoró-RN, CNPq fellow, <paulosergio@ufersa.edu.br> (corresponding author); ${ }^{3}$ Universidade Federal de Viçosa (doctorate program student), <pauloigor@alunos.ufersa.edu.br>; ${ }^{4}$ Professor, Biological Sciences Dep., Universidade do Estado do Rio Grande do Norte - UERN, 59610-090,<kmbsbarbosa@yahoo.com.br>; ${ }^{5}$ UFERSA (retired professor), <odaci@uol.com.br>; ${ }^{6}$ Student, UFERSA, Caixa Postal 137, 59600-970, Mossoró-RN, CNPq fellow, <jdantasjales@yahoo.com.br>, ${ }^{7}$ Student, UERN, <laerciomedeiros82@hotmail.com>.

Planta Daninha, Viçosa-MG, v. 28, n. 1, p. 69-76, 2010 
arbóreas quanto à freqüência de plantas daninhas sob suas copas. Contudo, o crescimento das plantas daninhas foi menor sob a copa da sabiá. Algaroba e sabiá apresentaram os maiores diâmetro da copa e altura da planta, mas apenas sabiá apresentou o maior diâmetro do caule. Em E2, as espécies perenes não diferiram quanto à freqüência e crescimento das plantas daninhas sob suas copas, mas a algaroba apresentou o maior crescimento, medido pelos diâmetros da copa e do caule e altura da planta.

Palavras-chave: Caatinga, composição florística.

\section{INTRODUCTION}

The semi-arid region of Northeastern Brazil covers an estimated area of 6 to $9 \times 105 \mathrm{~km}^{2}$, which represents nearly $10 \%$ of the Brazilian territory (Brasil, 2001). The ratio between trees adapted to the Brazilian Semi-Arid Region and the herbaceous vegetation under their respective canopies is an important study subject because of at least three aspects. First, if the trees represent the crop being exploited for the production of timber, fruits, or other purposes, the adjacent herbaceous vegetation assumes the role of weeds. When not controlled, weeds reduce the growth of perennial plants, negatively influencing stem diameter and height (Toledo et al., 2000), nutrient content (Ronchi et al., 2003) and yield (Carvalho et al., 1993) of crops.

Second, the information obtained about the ratio between trees and the herbaceous community that grows under their canopy can be useful for the identification of species with weed control potential (Piña-Rodrigues \& Lopes, 2001). A species associated with a smaller number or growth of weeds could be potentially useful for the control of these plants. The use of agroforestry systems in which pruning from trees is used to mulch the companion crops is an important area of research in the tropics. Plant species differ in their response to phytotoxic plant residues Gliricidia sepium mulch had no allelopathic effect on maize or beans but significantly decreased the population of some weed species (Obando, 1987). Mulches from G. sepium and $S$. siamea reduced weed density and weed biomass, while Leucaena leucocephala was less effective in reducing weed biomass and weed density (Kamara et al., 2000).

Finally, a third justification for studies such as the one herein reported is motivated by its connections to ecology and livestock farming. Trees of different species exert different effects on the herbaceous canopy present under the crown, in terms of composition and biomass (Harmand et al., 2003). An evaluation of the floristic composition of weeds in cultivations of tree species, either individually or in agroforestry systems, showed differences in the coefficient of similarity of weeds between the agrosystems (Souza et al., 2003). Herbaceous community growth, either under or outside the tree canopy, depends on the tree species under consideration (Menezes \& Salcedo, 1999).

The objectives of this work were to evaluate the floristic composition and biomass of weeds under the canopy of seven perennial species adapted to the Semi-Arid region of Brazil, and correlate these characteristics with growth traits of the perennial species.

\section{MATERIAL AND METHODS}

Two experiments were conducted at the "Rafae1 Fernandes" Experimental Farm (latitude $5^{\circ} 11^{\prime} \mathrm{S}$, longitude $37^{\circ} 20^{\prime} \mathrm{W}$ and altitude $18 \mathrm{~m})$. The experimental area was fallow (without agricultural use) for at least ten years. The mean maximum temperature in the region is between 32.1 and $34.5^{\circ} \mathrm{C}$ and the minimum is between 21.3 and $23.7^{\circ} \mathrm{C}$, with June and July as the coolest months. In view of the low latitude, the mean temperature does not present great annual variations. Since the region is located between the 500 and $700 \mathrm{~mm}$ isohyets, the climate, according to W. Köppen's classification, is ranked as type BSwh', that is, very hot with a summer rainy season that extends through the fall. The mean annual evapotranspiration is around $2000 \mathrm{~mm}$ and the mean insolation is 236 hours/month, with the driest months also being the months with the least insolation. 
The relative humidity is between 60.5 and $79.1 \%$ and the mean monthly wind speed ranges between 2.6 and $5.6 \mathrm{~m} \mathrm{~s}^{-1}$ (Carmo Filho $\&$ Oliveira, 1989).

The following species were evaluated: mesquite (Prosopis juliflora), jucá (Caesalpinia ferrea), white popinac (Leucaena leucocephala), mofumbo (Combretum leprosum), neem (Azadirachata indica), sabiá (Mimosa caesalpiniaefolia) and tamarind (Tamarindus indica). In experiment- 1 , the seven species were evaluated in a random block design with four replicates and nine plants per plot. In experiment-2, evaluations comprised four species (mesquite, jucá, white popinac, and tamarind) in a random block design with eight replicates and nine plants per plot.

Seed-propagated species were planted in January, 2003. The seeds were sown in black plastic bags, $32 \mathrm{~cm}$ tall and $25 \mathrm{~cm}$ in diameter, perforated in their bottom third. The bags were filled with substrate consisting of $1 / 3$ manure and $2 / 3$ soil. The soil was classified as a Red-Yellow Argisol, according to the Brazilian Soil Classification System (Embrapa, 1999) and as a Ferric Lixisol, according to the Soil Map of the World (Fao 1988). The soil analysis indicated: $\mathrm{pH}=6.8 ; \mathrm{Ca}=1.80 \mathrm{cmol}_{\mathrm{c}}^{-1} \mathrm{dm}^{-3} ; \mathrm{Mg}$ $=0.40 \mathrm{cmol}_{\mathrm{c}} \mathrm{dm}^{-3} ; \mathrm{K}=0.10 \mathrm{cmol}_{\mathrm{c}} \mathrm{dm}^{-3} ; \mathrm{Na}=$ $0.01 \mathrm{cmol}_{\mathrm{c}} \mathrm{dm}^{-3} ; \mathrm{Al}=0.00 \mathrm{cmol}_{\mathrm{c}} \mathrm{dm}^{-3} ; \mathrm{P}=$ $25 \mathrm{mg} \mathrm{dm}^{-3}$; Org. Matt. $=1.90 \mathrm{~g} \mathrm{~kg}^{-1}$. The manure analysis gave: $\mathrm{pH}$ (water) $=8.1 ; \mathrm{Ca}=$ $4.0 \mathrm{cmol}_{\mathrm{c}} \mathrm{dm}^{-3} ; \mathrm{Mg}=5.5 \mathrm{cmol}_{\mathrm{c}} \mathrm{dm}^{-3} ; \mathrm{K}=$ $1.72 \mathrm{cmol}_{\mathrm{c}} \mathrm{dm}^{-3} ; \mathrm{Na}=1.84 \mathrm{cmol}_{\mathrm{c}} \mathrm{dm}^{-3} ; \mathrm{Al}=$ $0.00 \mathrm{cmol}_{\mathrm{c}} \mathrm{dm}^{-3} ; \mathrm{P}=76.7 \mathrm{mg} \mathrm{dm}^{-3}$.

Transplanting was performed in March, 2003 , to a soil of the same type previously referred. The seedlings were transplanted to pits measuring $60 \times 60 \times 60 \mathrm{~cm}$. A circle with an area of $1.77 \mathrm{~m}^{2}$ was established around the trunk of each plant, two years after they were transplanted to the permanent location, in the beginning of the rainy period. The weeds collected within this circle were cut even with the ground, classified, weighed, and taken to a forced air circulation oven adjusted to a temperature of $70{ }^{\circ} \mathrm{C}$ until constant weight was achieved. At this time, plant height, and crown and stem diameters were evaluated in all plants of each plot. The mean diameter values for the crown or stem, measured in two perpendicular directions, were considered the crown and stem diameters, respectively. Stem diameter was measured at $10 \mathrm{~cm}$ above the ground with a digital caliper rule.

Calculations were made for index of occurrence, defined as the ratio between the number of trees under which a given weed species was found and the total number of trees in the experiment area, and for the frequency of weed occurrence, defined as the ratio between the number of weed plants in a given plot and the total number of weed species found in the experiment area.

The data for the evaluated characteristics were analyzed by the analysis of variance method. The ratio of number of species that occurred in each tree to total number of species that occurred in the experiment area were transformed to $\arcsin \sqrt{p}$ before analysis of variance, since it is a well-known fact that proportions tend to follow a binomial, rather than a normal distribution (Zar, 1999). The coefficient of linear correlation between tree species characteristics and weed characteristics was also estimated. The statistical analyses were performed using software developed by Universidade Federal de Viçosa (Ribeiro Júnior, 2001).

\section{RESULTS AND DISCUSSION}

Although the experiments conducted were different, the fact that they were grown in neighboring areas and during the same season, planted and managed in a similar manner, suggests some comparisons (Table 1). Forty-five weed species occurred in experiment-1, while only 37 were found in experiment-2. Some weed species that occurred in experiment-2 did not occur in experiment- 1 (and vice versa). In both experiments, some species occurred much more frequently than others. The species Adenocalymma sp. was the most frequent in both experiments, but the least frequent species were different in each experiment: Pavonia cancellata Cav. and Stylosanthes viscose Sw. were the least frequent in experiment-1, while Boerhavia diffusa L. and Cenchrus echinatus L. were the least frequent in experiment-2. 
Table 1 - Index of occurrence (ratio between the number of trees under which the weed species was found and the total number of trees in the experiment area) of weed species under the canopy of seven tree species in two experiments

\begin{tabular}{|c|c|c|c|c|c|c|c|}
\hline \multirow{3}{*}{$\begin{array}{l}\mathrm{N}^{\mathrm{o}} \\
\text { order }\end{array}$} & \multirow{3}{*}{ Weeds } & \multicolumn{2}{|c|}{ Experiment } & \multirow{3}{*}{$\begin{array}{l}\mathrm{N}^{\mathrm{o}} \\
\text { order }\end{array}$} & \multirow{3}{*}{ Weeds } & \multicolumn{2}{|c|}{ Experiment } \\
\hline & & 1 & 2 & & & 1 & 2 \\
\hline & & \multicolumn{2}{|c|}{$\begin{array}{l}\text { Index of } \\
\text { occurrence }\end{array}$} & & & \multicolumn{2}{|c|}{$\begin{array}{c}\text { Index of } \\
\text { occurrence }\end{array}$} \\
\hline 1 & Adenocalymma sp. & 63.72 & 87.25 & 24 & Jacquemontia serrata Meisn & 0.00 & 7.17 \\
\hline 2 & Alternanthera tenella Colla & 58.85 & 1.20 & 25 & Macroptilium lathyroides (L.) Urban & 46.90 & 52.19 \\
\hline 3 & Aniseia gracillima Choisy & 17.26 & 5.18 & 26 & $\begin{array}{l}\text { Macroptilium martii (Benth) Maréchal } \\
\text { et Baudet }\end{array}$ & 10.18 & 0.00 \\
\hline 4 & Aristida setifolia H.B.K. & 0.00 & 5.18 & 27 & Manihot glaziovii Muell. Arg. & 2.65 & 1.99 \\
\hline 5 & Boerhavia diffusa $\mathrm{L}$. & 3.10 & 0.40 & 28 & Merremia aegyptia (L.) Urban & 19.91 & 0.00 \\
\hline 6 & Cenchrus echinatus L. & 1.77 & 0.40 & 29 & $\begin{array}{l}\text { Neojobertia candolleana (Mart. Ex DC) } \\
\text { Bur. Ex K. Sch. }\end{array}$ & 8.85 & 3.59 \\
\hline 7 & $\begin{array}{l}\text { Centrosema pascuorum Mart. Ex } \\
\text { Benth. }\end{array}$ & 39.82 & 3.98 & 30 & Panicum maximum Jacq. & 10.62 & 1.20 \\
\hline 8 & Chaetocalyx sp. & 28.76 & 29.48 & 31 & Pavonia cancellata Cav. & 0.44 & 5.98 \\
\hline 9 & Chamaecrista $\mathrm{sp}$. & 41.59 & 27.89 & 32 & Piptadenia moniliformis & 1.33 & 3.19 \\
\hline 10 & Chamaecrista sp. & 12.39 & 1.59 & 33 & $\begin{array}{l}\text { Richardia grandiflora (Cham. Et } \\
\text { Schlecht.) }\end{array}$ & 0.88 & 0.00 \\
\hline 11 & Corchorus hirtus L. & 0.00 & 0.80 & 34 & Schranckia leptocarpa D.C. & 34.96 & 11.16 \\
\hline 12 & Croton glanoulosus Muell. Arg. & 1.77 & 0.00 & 35 & $\begin{array}{l}\text { Senna obtusifolia (L.) H.S. Irwin et R.C. } \\
\text { Barneby }\end{array}$ & 12.39 & 0.00 \\
\hline 13 & Croton obatus $\mathrm{L}$. & 1.33 & 0.00 & 36 & Sida $\mathrm{sp}$ & 1.77 & 0.80 \\
\hline 14 & Desmodium glabrum (Mill.) D.C. & 8.41 & 2.79 & 37 & Sida rhombifolia (L.) & 9.29 & 0.00 \\
\hline 15 & Digitaria sanguinalis (L.) Scop. & 3.54 & 0.40 & 38 & Spermacoce verticillata $\mathrm{L}$. & 6.19 & 64.94 \\
\hline 16 & Diodia teres & 23.01 & 14.34 & 39 & Stylosanthes viscose $\mathrm{Sw}$ & 0.44 & 4.78 \\
\hline 17 & Evolvulus ovatus M.L. Fernalo & 27.43 & 54.58 & 40 & Triunfetta longicoma St. Hil. & 2.21 & 21.91 \\
\hline 18 & $\begin{array}{l}\text { Froelichia humboldtiana (Roem. et } \\
\text { Schult.) Seub }\end{array}$ & 14.60 & 19.92 & 41 & Turnera sp. & 5.31 & 3.98 \\
\hline 19 & Hybanthus ipecacuantia Vent. & 3.54 & 8.37 & 42 & Turnera ulmifolia $\mathrm{L}$. & 18.58 & 7.97 \\
\hline 20 & Hyptis suaveolens $\mathrm{L}$. & 0.00 & 3.59 & 43 & Urochloa mosabicensis (Hackel.) Dardy & 2.65 & 1.20 \\
\hline 21 & Ipomoea asarifolia Roem et Schult & 15.49 & 0.00 & 44 & Waltheria indica $\mathrm{L}$. & 7.52 & 13.55 \\
\hline 22 & $\begin{array}{l}\text { Ipomoea bahiensis Willd. Ex Roem. Et } \\
\text { Schult. }\end{array}$ & 27.43 & 18.73 & 45 & Zornia gemella (Willd.) Vo g. & 3.98 & 0.80 \\
\hline 23 & $\begin{array}{l}\text { Jacquemontia densiflora (Meisn.) Hall. } \\
\text { F. }\end{array}$ & 2.65 & 12.35 & - & - & - & \\
\hline
\end{tabular}

There were variations in the number and type of species verified in the same block of experiment-1 (Table 2). For example, 20 species occurred in plots involving mofumbo and mesquite in the first block, but species type matching was only $70 \%$. That is, of all 20 species, only 14 occurred simultaneously in both of the plots mentioned. On the other hand, only 12 species occurred in the plot involving tamarind, and 25 species were found in the plot containing neem in that block. Similar observations can be made for the other blocks. On average, the smallest number of species was found in block 3 (16 species), and the highest occurred in block 4 (almost 20 species). Similar observations can be made for the data in experiment-2 (Table 3).
There were no differences between tree species for weed frequency under their canopies in experiment-1, but weed growth was smaller under the canopy of sabia trees (Table 4). Mesquite and sabia had the greatest plant height and crown diameter means, but only sabia had the greatest stem diameter (Table 4). Apparently no relation existed between tree and weed characteristics. For example, mesquite and sabia showed the same plant height and crown diameter, but were different with regard to weed growth under the canopy, as measured by dry matter. Mesquite and tamarind, which were quite different for crown diameter, did not differ in relation to weed growth. It was not evaluated the biomass of the weeds species individually. For this 
reason, it was not possible to determine the influence of tree species on specific growth of each type of weed.

In experiment-2, the perennial species were not different with regard to weed frequency and growth under their canopies, but mesquite had the greatest growth, as measured by plant height (with significant results for jucá as well) and crown and stem diameter (Table 5).

In addition to the harmful tree shading effect on the weeds that grow under the canopy, some trees also exert allelopathic effect on them (Saario et al., 2002). On the other hand, trees can be beneficial to the weeds by improving the chemical, physical, and biological properties of the soil under the canopy (Buresh \& Tian, 1998). Nutrient supply would increase by "capturing" nutrients from the soil layers below the root system of weeds. These nutrients become available for the weed species in the form of litter from tree branches and leaves. The increased supply of nutrients would also occur by a reduction in leaching and by the biological fixation of nitrogen. The availability of nutrients would increase via increased nutrient cycling and the conversion of nutrients to more labile forms. Greater soil water availability can be maintained under the trees due to rainwater interception and redistribution, reduction in evapotranspiration, and greater infiltration. Improvements can also be achieved in soil density and porosity, as well as in water distribution and infiltration into the soil. The decomposition of soil organic matter and plant residues is controlled by the soil biota, particularly by the macrofauna (Tian et al., 1992). The application of tree residues increases the populations of earthworms, termites, and ants (Tian et al., 1993).

With regard to the number and species of weeds that grow under a certain tree species,

Table 2 - Weed distribution in the experiment-1 area (the number next to the name of each tree represents the number of species in each plot, while numbers below the name of each species correspond to the numbers of species listed in Table 1)

\begin{tabular}{|c|c|c|c|}
\hline \multicolumn{4}{|c|}{ Blocks } \\
\hline 1 & 2 & 3 & 4 \\
\hline Sabiá (18) & Jucá (19) & Neem (17) & Mesquite (22) \\
\hline $\begin{array}{l}1,2,7,9,10,14,16,19,22, \\
25,26,28,29,30,34,35,37, \\
42\end{array}$ & $\begin{array}{l}1,2,7,8,9,10,14,15,16,18, \\
21,22,25,26,28,29,34,37 \\
42\end{array}$ & $\begin{array}{l}1,2,6,7,8,9,16,17,20,22 \\
25,28,30,34,37,41,42\end{array}$ & $\begin{array}{l}1,2,3,7,8,9,16,17,18,21 \\
22,23,25,29,30,33,34,37 \\
38,42,43,44\end{array}$ \\
\hline White popinac (19) & Mesquite (19) & Mesquite (19) & Neem $(20)$ \\
\hline $\begin{array}{l}1,2,3,7,8,9,10,14,21,22 \\
25,26,28,29,30,34,41,42, \\
44\end{array}$ & $\begin{array}{l}1,2,8,9,10,13,14,16,20 \\
21,22,25,28,30,34,37,38 \\
42,43\end{array}$ & $\begin{array}{l}1,2,6,7,8,9,10,14,16,17, \\
21,22,25,28,30,34,36,37, \\
42\end{array}$ & $\begin{array}{l}1,2,7,9,10,14,16,17,18 \\
21,22,25,28,30,33,34,37 \\
38,40,44\end{array}$ \\
\hline Mofumbo (20) & Tamarind (17) & Sabiá (15) & Mofumbo (20) \\
\hline $\begin{array}{l}1,2,5,6,7,9,10,13,14,16 \\
21,22,25,28,29,30,34,36 \\
41,42\end{array}$ & $\begin{array}{l}1,2,6,8,9,10,15,21,22,25 \\
28,29,34,35,36,42,43\end{array}$ & $\begin{array}{l}1,2,5,8,9,10,12,14,16,17 \\
22,25,28,34,38\end{array}$ & $\begin{array}{l}1,2,3,5,7,8,9,14,16,17 \\
18,19,25,29,34,37,38,40 \\
42\end{array}$ \\
\hline Tamarind (12) & White popinac (17) & Mofumbo (13) & White popinac (19) \\
\hline $\begin{array}{l}1,2,7,9,12,21,25,26,28 \\
34,35,42\end{array}$ & $\begin{array}{l}1,2,7,8,9,13,14,17,21,22 \\
25,28,34,35,36,41,42\end{array}$ & $\begin{array}{l}1,2,7,8,9,12,15,22,25,28 \\
34,35,42\end{array}$ & $\begin{array}{l}1,2,7,8,9,16,17,18,20,21 \\
22,23,25,28,29,34,38,42, \\
44\end{array}$ \\
\hline Mesquite (20) & Sabiá (15) & White popinac (17) & Sabiá (23) \\
\hline $\begin{array}{l}1,2,6,7,8,9,10,15,21,22, \\
25,26,27,28,30,34,41,42, \\
43,44\end{array}$ & $\begin{array}{l}1,2,7,8,9,15,19,21,22,25 \\
26,27,30,42,43\end{array}$ & $\begin{array}{l}1,2,3,7,8,9,10,15,16,17 \\
22,26,29,30,41,42,44\end{array}$ & $\begin{array}{l}1,2,3,7,8,9,14,16,17,20 \\
22,23,25,29,34,35,38,40 \\
41,42,43,44,45\end{array}$ \\
\hline Neem (25) & Mofumbo (20) & Jucá (18) & Tamarind (16) \\
\hline $\begin{array}{l}1,2,5,7,8,9,10,14,15,16, \\
17,18,20,21,22,25,26,27, \\
28,30,34,41,42,43,44\end{array}$ & $\begin{array}{l}1,2,3,5,7,8,9,14,16,17, \\
19,21,22,25,26,29,34,37, \\
41,44\end{array}$ & $\begin{array}{l}1,2,3,7,8,9,10,16,17,18 \\
22,25,26,29,37,39,41,44\end{array}$ & $\begin{array}{l}1,3,7,8,9,10,16,17,18,19 \\
22,25,29,31,37,45\end{array}$ \\
\hline Jucá (15) & Neem (18) & Tamarind (13) & Jucá (17) \\
\hline $\begin{array}{l}1,2,3,7,9,14,16,17,18,22, \\
25,29,34,41,44\end{array}$ & $\begin{array}{l}1,2,3,7,8,9,10,15,16,17 \\
18,19,22,27,32,34,37,45\end{array}$ & $\begin{array}{l}2,3,7,8,9,16,17,18,20,22 \\
27,30,39\end{array}$ & $\begin{array}{l}2,3,7,8,9,16,17,18,22,23, \\
27,29,32,38,40,42,45\end{array}$ \\
\hline
\end{tabular}


Table 3 - Weed distribution in the experiment-2 area (the number next to the name of each tree represents the number of species in each plot, while numbers below the name of each species correspond to the numbers of species listed in Table 1)

\begin{tabular}{|c|c|c|c|c|c|c|c|}
\hline $\mathrm{B}^{1 /}$ & Tamarind (17) & B & Mesquite (19) & B & Jucá (13) & B & Mesquite (15) \\
\hline \multirow{7}{*}{1} & $\begin{array}{l}1,3,7,8,9,14,16,17,18 \\
22,23,25,31,33,34,38,42\end{array}$ & \multirow{7}{*}{3} & $\begin{array}{l}1,8,9,16,17,18,19,20,23 \\
25,30,31,33,38,40,41,42, \\
43,44\end{array}$ & \multirow{7}{*}{5} & $\begin{array}{l}1,8,9,16,17,18,19,25 \\
31,33,38,40,44\end{array}$ & \multirow{7}{*}{7} & $\begin{array}{l}1,4,8,9,15,17,18,22,24, \\
25,31,38,40,42,44\end{array}$ \\
\hline & White popinac (21) & & White popinac (19) & & Mesquite (17) & & Jucá (15) \\
\hline & $\begin{array}{l}1,2,3,7,8,9,10,14,16 \\
17,18,20,22,23,25,34, \\
38,39,41,42,44\end{array}$ & & $\begin{array}{l}1,8,9,10,16,17,18,19,20 \\
22,23,25,31,34,38,39,40 \\
42,44\end{array}$ & & $\begin{array}{l}1,2,8,9,16,17,18,23,24, \\
25,29,31,38,40,41,43, \\
44\end{array}$ & & $\begin{array}{l}1,4,6,8,9,17,19,22,23 \\
24,25,34,38,40,44\end{array}$ \\
\hline & Jucá (18) & & Tamarind (11) & & Tamarind (16) & & White popinac(12) \\
\hline & $\begin{array}{l}1,3,7,8,9,14,16,17,18, \\
22,23,25,27,36,38,40, \\
42,45\end{array}$ & & $\begin{array}{l}1,8,9,17,18,22,23,25,34 \\
38,44\end{array}$ & & $\begin{array}{l}1,4,8,9,16,17,18,20,22 \\
24,25,29,38,40,42,44\end{array}$ & & $\begin{array}{l}1,4,8,9,10,17,18,24,25, \\
32,38,40\end{array}$ \\
\hline & Mesquite (17) & & Jucá (15) & & White popinac (14) & & Tamarind (4) \\
\hline & $\begin{array}{l}1,3,9,11,16,17,20,22, \\
23,25,29,31,34,36,38, \\
40,42\end{array}$ & & $\begin{array}{l}1,3,5,8,9,16,17,18,19 \\
22,25,32,34,38,44\end{array}$ & & $\begin{array}{l}1,4,8,14,16,17,19,20 \\
25,27,29,38,39,44\end{array}$ & & $1,16,22,24$ \\
\hline \multirow{8}{*}{2} & Tamarind (18) & \multirow{8}{*}{4} & Mesquite (12) & \multirow{8}{*}{6} & Jucá (16) & \multirow{8}{*}{8} & Jucá (15) \\
\hline & $\begin{array}{l}1,3,7,8,9,10,14,16,17 \\
18,22,23,25,34,38,40, \\
42,44\end{array}$ & & $\begin{array}{l}1,8,9,16,17,18,19,23,25 \\
38,40,44\end{array}$ & & $\begin{array}{l}1,7,8,9,16,17,18,19,22, \\
25,29,38,40,41,42,44\end{array}$ & & $\begin{array}{l}1,4,8,9,16,17,18,22,23, \\
24,25,29,40,42,44\end{array}$ \\
\hline & Mesquite (17) & & White popinac (13) & & Mesquite (12) & & Mesquite (15) \\
\hline & $\begin{array}{l}1,2,7,8,9,16,17,18,19, \\
22,23,25,34,38,40,42,44\end{array}$ & & $\begin{array}{l}1,8,9,16,17,19,22,25,27, \\
29,34,38,40\end{array}$ & & $\begin{array}{l}1,4,8,9,16,17,18,25,30, \\
38,40,44\end{array}$ & & $\begin{array}{l}1,4,8,16,17,18,19,22, \\
23,25,32,34,38,39,40\end{array}$ \\
\hline & Jucá (15) & & Tamarind (13) & & White popinac (14) & & Tamarind $(8)$ \\
\hline & $\begin{array}{l}1,7,8,9,16,17,18,22,23, \\
25,26,33,34,38,44\end{array}$ & & $\begin{array}{l}1,8,9,17,22,23,25,31,32 \\
34,38,39,44\end{array}$ & & $\begin{array}{l}1,4,8,16,17,18,22,24 \\
25,29,32,34,38,44\end{array}$ & & $1,16,17,18,22,22,25,38$ \\
\hline & White popinac (18) & & Jucá (13) & & Tamarind (11) & & White popinac(10) \\
\hline & $\begin{array}{l}1,3,7,8,9,16,17,18,19 \\
22,23,25,33,38,40,41, \\
42,45\end{array}$ & & $\begin{array}{l}1,3,8,11,17,18,19,25,27 \\
31,32,38,44\end{array}$ & & $\begin{array}{l}1,4,8,9,17,19,24,32,38, \\
39,43\end{array}$ & & $\begin{array}{l}1,4,8,17,18,24,29,31, \\
38,39\end{array}$ \\
\hline
\end{tabular}

${ }^{1 /}$ Block.

interspecific and intraspecific interactions may occur that influence the composition and growth of weeds as a whole, which, in turn, should depend on other environmental factors (Britton et al., 2003). Such interactions can facilitate or discourage the development of certain weed species.

The same factors that affect weed growth under the canopy of trees may influence the floristic composition of those species under the canopy, which would explain the variability in the distribution of weed species observed in the experiments upon which the present work was based (Tables 3 and 4).

Despite the apparent lack of correlation between tree crown diameter and the growth of weeds under them (Tables 4 and 5), the linear correlation coefficient between these two traits was negative in experiment- 1 (Table 6). Discrepancies between analysis of variance and regression analysis are well-known, i.e., the first type of analysis may fail to indicate differences between treatments, while the regression analysis is indicating that an equation should be fitted. This suggests that discrepancies may occur between analysis of variance and correlation analysis, such as those found in the present work. The means comparison test compared the diameter means between two species, whereas the linear correlation coefficient calculation considered the values for crown diameter and dry matter of the above-ground part of weeds associated with all tree species evaluated. Besides, in addition to canopy diameter, stem diameter and plant height, other characteristics related to the canopy must be involved, such as branch distribution, number of leaves per plant, leaf area, root system, etc. Senna siamea, in spite of having an "open" canopy, in relation to two other tree species, showed a strong depressive effect on its herbaceous understory, probably due to its greater mass of fine roots (Harmand et al., 2003). In spite of the potential importance of crop plant architecture for weed control, 
especially with respect to shading effects, evaluations of luminosity under the canopy of trees were not made in the present work. Finally, the allelopathy must not be forgotten. Different tree species could influence weed growth differently under the canopy by means of allelopathy. In this respect, the allelopathic potential of sabia on seeds of Tabebuia alba
(Piña-Rodrigues \& Lopes, 2001), white popinac on weeds (Prates et al., 2003), and perhaps of other species evaluated in the present study is worth mentioning.

There was a positive correlation between the frequencies of weed species and growth characteristics in experiment-2, as well as in

Table 4 - Frequency (number of weed species/total number of weed species in the experiment area) and dry matter in the aboveground part of weeds, plant height, stem and crown diameters of plant species adapted to the Brazilian Semi-Arid in experiment- $1^{1}$ '

\begin{tabular}{|l|c|c|c|c|c|}
\hline \multirow{2}{*}{ Trees } & \multicolumn{2}{|c|}{ Weeds } & \multicolumn{2}{c|}{ Trees } \\
\cline { 2 - 6 } & $\begin{array}{c}\text { Frequency } \\
(\%)\end{array}$ & $\begin{array}{c}\text { Dry matter } \\
\left(\mathrm{g} \mathrm{m}^{-2}\right)\end{array}$ & $\begin{array}{c}\text { Plant height } \\
(\mathrm{m})\end{array}$ & $\begin{array}{c}\text { Crown } \\
\text { diameter }(\mathrm{m})\end{array}$ & $\begin{array}{c}\text { Stem } \\
\text { diameter }(\mathrm{mm})\end{array}$ \\
\hline Mesquite & $48.8 \mathrm{a}$ & $365.0 \mathrm{a}$ & $3.93 \mathrm{a}$ & $4.92 \mathrm{a}$ & $80.7 \mathrm{ab}$ \\
\hline Jucá & $42.1 \mathrm{a}$ & $395.9 \mathrm{a}$ & $3.16 \mathrm{ab}$ & $2.68 \mathrm{~b}$ & $51.9 \mathrm{~cd}$ \\
\hline White popinac & $45.1 \mathrm{a}$ & $338.5 \mathrm{ab}$ & $3.05 \mathrm{ab}$ & $2.76 \mathrm{~b}$ & $76.2 \mathrm{bc}$ \\
\hline Mofumbo & $44.5 \mathrm{a}$ & $366.4 \mathrm{a}$ & $2.75 \mathrm{~b}$ & $3.44 \mathrm{~b}$ & $65.1 \mathrm{bc}$ \\
\hline Neem & $48.8 \mathrm{a}$ & $406.9 \mathrm{a}$ & $3.74 \mathrm{ab}$ & $2.66 \mathrm{~b}$ & $85.3 \mathrm{ab}$ \\
\hline Sabiá & $41.8 \mathrm{a}$ & $185.4 \mathrm{~b}$ & $3.88 \mathrm{a}$ & $5.22 \mathrm{a}$ & $104.9 \mathrm{a}$ \\
\hline Tamarind & $35.4 \mathrm{a}$ & $427.7 \mathrm{a}$ & $1.56 \mathrm{c}$ & $1.47 \mathrm{c}$ & $35.6 \mathrm{~d}$ \\
\hline CV, \% & 8.3 & 18.9 & 13.8 & 13.8 & 17.0 \\
\hline
\end{tabular}

${ }^{1 /}$ Means followed by the same letter are not different at $5 \%$ probability by Tukey test.

Table 5 - Frequency (number of weed species/total of weed species in the experiment area) and dry matter in the above-ground part of weeds, plant height, root collar and crown diameters of four plant species adapted to the Brazilian Semi-Arid Region ${ }^{1 /}$

\begin{tabular}{|l|c|c|c|c|c|}
\hline \multirow{2}{*}{ Trees } & \multicolumn{2}{|c|}{ Weeds } & \multicolumn{2}{c|}{ Trees } \\
\cline { 2 - 6 } & $\begin{array}{c}\text { Frequency } \\
(\%)\end{array}$ & $\begin{array}{c}\text { Dry matter } \\
\left(\mathrm{g} \mathrm{m}^{-2}\right)\end{array}$ & $\begin{array}{c}\text { Plant height } \\
(\mathrm{m})\end{array}$ & $\begin{array}{c}\text { Crown } \\
\text { diameter }(\mathrm{m})\end{array}$ & $\begin{array}{c}\text { Stem } \\
\text { diameter }(\mathrm{mm})\end{array}$ \\
\hline Mesquite & $41.9 \mathrm{a}$ & $639.9 \mathrm{a}$ & $2.91 \mathrm{a}$ & $3.16 \mathrm{a}$ & $52.2 \mathrm{a}$ \\
\hline Jucá & $40.5 \mathrm{a}$ & $535.2 \mathrm{a}$ & $3.11 \mathrm{a}$ & $2.62 \mathrm{~b}$ & $41.9 \mathrm{~b}$ \\
\hline White popinac & $41.0 \mathrm{a}$ & $540.6 \mathrm{a}$ & $2.30 \mathrm{~b}$ & $1.65 \mathrm{c}$ & $43.0 \mathrm{~b}$ \\
\hline Tamarind & $33.1 \mathrm{a}$ & $566.4 \mathrm{a}$ & $1.11 \mathrm{c}$ & $1.06 \mathrm{~d}$ & $19.1 \mathrm{c}$ \\
\hline $\mathrm{CV}, \%$ & 11.9 & 13.5 & 15.1 & 18.5 & 14.4 \\
\hline
\end{tabular}

${ }^{1 /}$ Means followed by the same letter are not different at $5 \%$ probability by Tukey test.

Table 6 - Coefficient of linear correlation between characteristics of trees and weeds under the canopy of the trees, in two experiments

\begin{tabular}{|l|c|c|c|c|}
\hline \multirow{2}{*}{ Species (trees) } & \multicolumn{2}{|c|}{ Experiment-1 } & \multicolumn{2}{c|}{ Experiment-2 } \\
\cline { 2 - 5 } & \multicolumn{2}{|c|}{ Weeds } & \multicolumn{2}{c|}{ Weeds } \\
\cline { 2 - 5 } & Frequency & $\begin{array}{c}\text { Dry matter in the } \\
\text { above-ground part }\end{array}$ & Frequency & $\begin{array}{c}\text { Dry matter in the } \\
\text { above-ground part }\end{array}$ \\
\hline Plant height & $0.34^{\mathrm{ns}}$ & $-0.36^{\mathrm{ns}}$ & $0.48^{*}$ & $0.03^{\mathrm{ns}}$ \\
\hline Stem diameter & $0.39^{*}$ & $-0.58^{*}$ & $0.54^{*}$ & $0.09^{\mathrm{ns}}$ \\
\hline Crown diameter & $0.34^{\mathrm{ns}}$ & $-0.55^{*}$ & $0.47^{*}$ & $0.29^{\mathrm{ns}}$ \\
\hline
\end{tabular}

ns, $*=$ non-significant and significant at $5 \%$ probability, by the test, respectively. 
one case in experiment- 1 (Table 6). Although the linear correlation coefficient not always indicates a cause-and-effect relationship between two variables, perhaps the beneficial effect that trees may have on the soil properties, favoring greater weed richness, could explain this type of correlation.

It can be concluded that in experiment- 1 there were no differences between tree species as to weed frequency under their canopies; however, weed growth was smaller under the canopy of sabia trees. Mesquite and sabiá had the greatest plant height and crown diameter means, but only sabia had the greatest stem diameter. In experiment-2, the perennial species were not different with regard to weed frequency and growth under their canopies, but mesquite had the greatest growth, as measured by plant height (with significant results for jucá as well) and crown and stem diameter.

\section{LITERATURE CITED}

BRASIL. Ministério do Meio Ambiente. Uso sustentável dos recursos florestais e conservação da biodiversidade da Caatinga. Brasília: 2001. 34 p.

BRITTON, A. et al. The influence of soil-type, drought and nitrogen addition on interactions between Calluna vulgaris and Deschampsia flexuosa: implications for heathland regeneration. Plant Ecol., v. 166, n. 1, p. 93-105, 2003.

BURESH, R. J.; TIAN, G. Soil improvement by trees in subSaharan Africa. Agrof. Syst., v. 38, n. 1, p. 51-76, 1998.

CARMO FILHO, F.; OLIVEIRA, O. F. Mossoró: um município do semi-árido nordestino. Mossoró: Fundação Guimarães Duque/ESAM, 1989. 62 p. (Coleção

Mossoroense, Séria B, n. 672)

CARVALHO, J. E. B. et al. Influência das épocas de controle das plantas daninhas na produção de laranja 'Pera'.

Planta Daninha, v. 11, n. 1, p. 49-54, 1993.

EMPRESA BRASILEIRA DE PESQUISAAGROPECUÁRIA - EMBRAPA. Centro Nacional de Pesquisa do Solo. Sistema brasileiro de classificação de solos. Brasília: Serviço de Produção de Informação, 1999. 412 p.

FAO. Soil map of the world: revised legend. Rome: UNESCO, 1988. $119 \mathrm{p}$

HARMAND, J. M.; DONFACK, P.; NJTI, C. F. Tree-root systems and herbaceous species-characteristics under tree species introduced into grazing lands in subhumid Cameroon. Agrof. Syst., v. 59, n. 2, p. 131-140, 2003.
KAMARA, A. Y. et al. Selective control of weeds in an arable crop by mulches from some multipurpose trees in Southwester Nigeria. Agrof. Syst., v. 50, n. 1, p. 17-26, 2000.

MENEZES, R. S. C.; SALCEDO, I. H. Influence of tree species on the herbaceous understory and soil chemical characteristics in a silvopastoral system in semi-arid Northeastern Brazil. R. Bras. Ci. Solo, v. 23, n. 4, p. 817-826, 1999.

OBANDO, L. Potencial alelopatico de Gliricidia sepium (Jacq.) Walp. sobre los cultivos de maiz y frijol y las malezas predominantes (abstract) In: WASHINGTON, D.; GLOVER, N.; BREWBAKER, J. L. (Eds.). Gliricídia sepium (Jacq.) Walp., management and improvement, Turrialba: Nitrogen Fixing Tree Association (NFTA), 1987. p. 59-60. (Special Publication, 87-01)

PIÑA-RODRIGUES, F. C. M.; LOPES, B. M. Potencial aleopático de Mimosa caesalpinaefolia Benth sobre sementes de Tabebuia alba (Cham.) Sandw. Flor. Amb., v. 8, n. 1, p. 130-136, 2001.

PRATES, H. T.; PIRES, N. M.; PREIRA FILHO, I. A Controle de plantas daninhas na cultura do milho utilizando leucena (Leucaena leucocephala (Lam.) De Wit). R. Bras. Milho Sorgo, v. 2, n. 2, p. 36-43, 2003.

RIBEIRO JÚNIOR, J. I. Análises estatísticas no SAEG Viçosa, MG: Universidade Federal de Viçosa, 2001. 301 p.

RONCHI, C. P. et al. Acúmulo de nutrientes pelo cafeeeiro sob interferência de plantas daninhas. Planta Daninha, v. 21, n. 2, p. 219-227, 2003.

SAARIO, M. et al. Allelopathic potential of lingonberry (Vaccinium vitis-idaea L.) litter for weed control. Biol. Agric. Hortic., v. 20, n. 1, p. 11-28, 2002

SOUZA, L. S. A.; SILVA, J. F.; SOUZA, M. D. B Composição florística de plantas daninhas em agrossistemas de cupuazeiro (Theobroma grandiflorum) e pupunheira (Bactris gasipaes). Planta Daninha, v. 21, n. 2, p. 249-255, 2003

TIAN, G.; KANG, B. T.; BRUSSAARD, L. Biological effects of plant residues with contrasting chemical compositions under humid tropical conditions - decomposition and nutrient release Soil Biol. Biochem., v. 24, n. 10, p. 1051-1060, 1992.

TIAN, G.; BRUSSAARD, L.; KANG, B. T. Biological effects of plant residues with contrasting chemical compositions under humid tropical conditions: Effects on soil fauna, decomposition and nutrient release. Soil Biol. Biochem., v. 25, n. 6, p. $731-737,1993$.

TOLEDO, R. E. B. et al. Efeitos da faixa de controle do capimbraquiária (Brachiaria decumbens) no desenvolvimento inicial de plantas de eucalipto. Planta Daninha, v. 18, n. 3, p. 383393,2000

ZAR, J. H. Biostatistical analysis. 4.ed. Upper Saddle River, Prentice Hall, 1999. 663 p. 